\title{
ADAM-10-Mediated N-Cadherin Cleavage Is Protein Kinase C- $\alpha$ Dependent and Promotes Glioblastoma Cell Migration
}

\author{
Zachary A. Kohutek, ${ }^{1}$ Charles G. diPierro, ${ }^{2}$ Gerard T. Redpath, ${ }^{1}$ and Isa M. Hussaini ${ }^{1}$ \\ Departments of ${ }^{1}$ Pathology and ${ }^{2}$ Molecular Physiology and Biological Physics, University of Virginia Health System, Charlottesville, Virginia 22908
}

\begin{abstract}
MMPs (matrix metalloproteinases) and the related "a disintegrin and metalloproteinases" (ADAMs) promote tumorigenesis by cleaving extracellular matrix and protein substrates, including $\mathrm{N}$-cadherin. Although $\mathrm{N}$-cadherin is thought to regulate cell adhesion, migration, and invasion, its role has not been characterized in glioblastomas (GBMs). In this study, we investigated the expression and function of posttranslational $\mathrm{N}$-cadherin cleavage in GBM cells as well as its regulation by protein kinase $\mathrm{C}$ (PKC). N-Cadherin cleavage occurred at a higher level in glioblastoma cells than in non-neoplastic astrocytes. Treatment with the PKC activator phorbol 12-myristate 13-acetate (PMA) increased N-cadherin cleavage, which was reduced by pharmacological inhibitors and short interfering RNA (siRNA) specific for ADAM-10 or PKC- $\alpha$. Furthermore, treatment of GBM cells with PMA induced the translocation of ADAM-10 to the cell membrane, the site at which N-cadherin was cleaved, and this translocation was significantly reduced by the PKC- $\alpha$ inhibitor Gö6976 [12-(2-cyanoethyl)6,7,12,13-tetrahydro-13-methyl-5-oxo-5H-indolo[2,3-a]pyrrolo[3,4-c]carbazole] or PKC- $\alpha$ short hairpin RNA. In functional studies, $\mathrm{N}$-cadherin cleavage was required for GBM cell migration, as depletion of $\mathrm{N}$-cadherin cleavage by $\mathrm{N}$-cadherin siRNA, ADAM-10 siRNA, or a cleavage-site mutant $\mathrm{N}$-cadherin, decreased GBM cell migration. Together, these results suggest that $\mathrm{N}$-cadherin cleavage is regulated by a PKC- $\alpha$-ADAM-10 cascade in GBM cells and may be involved in mediating GBM cell migration.
\end{abstract}

\section{Introduction}

Gliomas are the most common type of primary brain tumor in adults, and over one-half are classified as World Health Organization (WHO) grade IV astrocytoma, or glioblastoma multiforme (GBM) (Central Brain Tumor Registry of the United States, 2005). These tumors invade extensively throughout the brain parenchyma, thus making them one of the most lethal tumors (Lacroix et al., 2001). As glioblastoma cells acquire their infiltrative phenotype, they overexpress various matrix metalloproteinases (MMPs), a family of zinc-dependent endopeptidases that cleave extracellular matrix components (Stamenkovic, 2003). In addition to their role in extracellular matrix degradation, many MMPs and the related family of "a disintegrin and metalloproteinases" (ADAMs) regulate proliferation, adhesion, migration, and metastasis by initiating the cleavage of cell surface proteins (Huovila et al., 2005). Activation of the protein kinase $\mathrm{C}$ (PKC) family of phospholipid-dependent serine/threonine kinases, which also promote cancer progression (Acevedo-Duncan et al., 2002; Nakashima, 2002; Koivunen et al., 2006), can induce MMP-mediated cell surface protein cleavage (Reiss et al., 2005; Covington et al., 2006). Because glioma cells have increased PKC

Received 0ct. 22, 2008; revised Feb. 17, 2009; accepted March 6, 2009.

This work was supported by National Institute of Neurological Disorders and Stroke Award F31NS063644 (Z.A.K.) as well as National Cancer Institute Grant CA90851 (I.M.H.). We thank Ruoya Ho (Somlyo Laboratory) for confocal microscopy assistance. We also thank Dr. A. Ludwig (University of Kiel, Kiel, Germany) for providing the ADAM inhibitors and Dr. A. Kinoshita (Kyoto University, Kyoto, Japan) for providing the wild-type and mutant $\mathrm{N}$-cadherin plasmids. The content is solely the responsibility of the authors and does not necessarily represent the official view of the National Institute of Neurological Disorders and Stroke or National Cancer Institute.

Correspondence should be addressed to Zachary A. Kohutek, Department of Pathology, University of Virginia Health System, P.0. Box 800904, Charlottesville, VA 22908. E-mail: zsk3k@virginia.edu.

D0I:10.1523/JNEUROSCI.5126-08.2009

Copyright $\odot 2009$ Society for Neuroscience $\quad$ 0270-6474/09/294605-11\$15.00/0 activity (Couldwell et al., 1991; Todo et al., 1991), the possibility exists that PKC-induced cleavage of cell surface substrates by MMP/ADAMs may play an important role in glioma biology.

One substrate of MMP/ADAM-mediated cleavage is $\mathrm{N}$-cadherin, a type I transmembrane glycoprotein that forms adherens junctions between cells by interacting with other cadherin molecules via its extracellular domain. Remodeling of these junctions can occur as N-cadherin undergoes MMP/ADAMmediated cleavage in its extracellular domain, yielding a functional $\sim 90 \mathrm{kDa}$-terminal fragment and a $\sim 40 \mathrm{kDa}$-terminal fragment, CTF1 (Uemura et al., 2006). Presenilin-1 (PS1) $/ \gamma$ secretase then cleaves CTF1 to produce the $\sim 35 \mathrm{kDa}$ fragment CTF2, which is released into the cytoplasm. The functional consequences of this cleavage event are not entirely clear, but it has been suggested that CTF2 regulates gene transcription (Marambaud et al., 2003), whereas the N-terminal fragment promotes neurite outgrowth, angiogenesis, or migration (Paradies and Grunwald, 1993; Utton et al., 2001; Derycke et al., 2006).

$\mathrm{N}$-cadherin is expressed at high levels during embryogenesis and is permanently expressed by cells derived from neural ectoderm, including glia and neurons (Hatta et al., 1987). Although its expression in most adult tissues is low (Tsuchiya et al., 2006), reexpression of $\mathrm{N}$-cadherin during tumor progression has been suggested to promote cell migration and metastasis (Kim et al., 2000; Cavallaro, 2004; Qi et al., 2005). In astrocytic tumors, however, studies attempting to link $\mathrm{N}$-cadherin expression to tumor grade or invasiveness have reached conflicting conclusions (Barami et al., 2006), and no studies have yet investigated the role of $\mathrm{N}$-cadherin posttranslational cleavage in gliomas.

Because of the key role of $\mathrm{N}$-cadherin in cell adhesion and motility, its posttranslational processing may be an important 
mechanism contributing to tumor progression. In this study, we demonstrate that GBM cells cleave higher amounts of $\mathrm{N}$-cadherin than normal astrocytes and that maximal cleavage requires the metalloproteinase ADAM-10. Furthermore, we provide evidence to support the hypothesis that $\mathrm{N}$-cadherin cleavage functions to increase tumor cell migration in vitro and can be initiated by the activation of PKC- $\alpha$.

\section{Materials and Methods}

Antibodies and reagents. Phorbol 12-myristate 13-acetate (PMA), puromycin, $\{1 S$-benzyl-4R-[1-(1S-carbamoyl-2-phenylethylcarbamoyl)-1S-3methylbutylcarbamoyl]-2R-hydroxy-5-phenylpentyl $\}$ carbamic acid tertbutyl ester (L-685,458), and anti-tubulin antibody were purchased from Sigma-Aldrich. ADAM-10 antibody B3, as well as anti-hemagglutinin (HA), anti-epidermal growth factor receptor (EGFR), anti-PKC- $\alpha$, anti-PKC- $\delta$, and anti-PKC- $\gamma$ were purchased from Santa Cruz Biotechnology. $\mathrm{N}$-Cadherin C-terminal antibody clone 32 was acquired from BD Biosciences, polyclonal rabbit anti-N-cadherin antibody for immunofluorescence was from Abcam, and anti-p38 was from Cell Signaling. Alexa 488 goat anti-mouse, rhodamine goat anti-mouse, and phycoerythrin (PE)-Annexin $\mathrm{V}$ antibodies were from Invitrogen. The PKC inhibitors bisindolylmaleimide, 12-(2-cyanoethyl)-6,7,12,13-tetrahydro-13-methyl-5-oxo-5H-indolo [2,3-a]pyrrolo[3,4-c] carbazole (Gö6976), and hispidin, as well as carbobenzoxy-L-leucyl-L-leucyl-L-leucinal (MG-132), N-[(2R)-2(hydroxamideocarbonylmethyl)-4-methylpantanoyl]-L-tryptophan methylamide (GM6001), and (4-(4-(methanesulfonamido)phenoxy)phenylsulfonyl) methylthiirane (SB-3CT $p$ MS) were purchased from EMD Biosciences. Chloroquine was purchased from Sigma-Aldrich. The ADAM inhibitors $(2 R, 3 S)$-3-(formyl-hydroxyamino)-2-(3-phenyl-1-propyl) butanoic acid [(1S)-2,2-dimethyl-1-methylcarbamoyl-1-propyl] amide (GI254023X) and $(2 R, 3 S)$-3-(formyl-hydroxyamino)-2-(2-methyl-1-propyl) hexanoic acid [(1S)-5-benzyloxycarbamoylamino-1-(1,3-thiazol-2-ylcarbamoyl)-1pentyl] amide (GW280264X) were a generous gift from Dr. Andreas Ludwig (University of Kiel, Kiel, Germany). Lentiviral short hairpin RNA (shRNA) for PKC- $\alpha$ was acquired from Sigma-Aldrich, and N-cadherin and ADAM-10 siRNA were purchased from Dharmacon. Wild-type C-terminally HA-tagged $\mathrm{N}$-cadherin and an HA-tagged mutant $\mathrm{N}$-cadherin containing two amino acid substitutions in its $\mathrm{N}$-terminal cleavage site were a kind gift from Dr. A. Kinoshita (Kyoto University, Kyoto, Japan) (Uemura et al., 2006). Empty vector pcDNA3 was acquired from Invitrogen. Human $\operatorname{IgG}(\mathrm{Fc})$ fragment was purchased from Alpha Diagnostic International, and recombinant human $\mathrm{N}$-cadherin/Fc chimera (1388-NC) was purchased from R\&D Systems.

Cell cultures and human samples. Human glioblastoma cell lines U-1242 MG and U-251 MG have been described previously (Hussaini et al., 2000). Normal human astrocytes (NHAs) were originally derived from a single culture of fetal brain astrocytes and were obtained from Lonza Walkersville. GBM\#6 and GBM\#8 primary cell lines were acquired from Dr. David James (University of California, San Francisco, San Francisco, CA). Cells were cultured to $90 \%$ confluence in MEM- $\alpha$ growth medium (Invitrogen) supplemented with $10 \%$ fetal bovine serum (HyClone) and $1 \%$ penicillin/streptomycin (Invitrogen) at $37^{\circ} \mathrm{C}$ in $4.8 \%$ $\mathrm{CO}_{2}, 90 \%$ relative humidity, and passed every $5-7 \mathrm{~d}$. GBM specimens and non-neoplastic temporal lobe specimens from epilepsy patients were flash frozen in liquid nitrogen after surgical removal and stored at $-80^{\circ} \mathrm{C}$ until protein extraction. The GBM specimens were from patients aged 60-82 and were characterized as WHO grade IV astrocytomas by our neuropathologist, Dr. Beatriz Lopes (University of Virginia, Charlottesville, VA). The temporal lobe epilepsy specimens were from patients aged $20-32$.

Western blot analysis. Cells were rinsed with $1 \times \mathrm{PBS}$ and protein was extracted using Triton lysis buffer [1\% Triton X-100, 50 mm Tris, pH 7.5, $150 \mathrm{~mm} \mathrm{NaCl}, 2 \mathrm{~mm}$ EDTA, and protease inhibitor mixture (SigmaAldrich)], unless otherwise noted. Western blot analysis was performed as previously described (Hussaini et al., 2000). Densitometry was performed using ImageQuant 5.2 software (GE Healthcare).

Cell membrane fractionation. Cells were washed once with cold PBS and $0.5 \mathrm{ml}$ of hypotonic lysis buffer A (10 mM HEPES, pH 7.9, $10 \mathrm{~mm}$
$\mathrm{KCl}, 0.1 \mathrm{~mm}$ EDTA, $0.1 \mathrm{~mm}$ EGTA, $1 \mathrm{~mm}$ DTT) was added to each $10 \mathrm{~cm}$ dish. Cells were then scraped and transferred to a $1.5 \mathrm{ml}$ Eppendorf tube, incubated on ice for $20 \mathrm{~min}$ to allow for cell swelling, homogenized with 40 strokes in a tight Dounce homogenizer, and centrifuged at 12,000 $\times g$ for $30 \mathrm{~s}$ at $4^{\circ} \mathrm{C}$ to pellet the nuclei. Postnuclear supernatants were then centrifuged at $100,000 \times g$ for $60 \mathrm{~min}$ at $4^{\circ} \mathrm{C}$ to pellet membranes. The supernatant (cytosolic fraction) was combined with $5 \times$ sample buffer, whereas the pellet (membrane fraction) was resuspended in $1 \times$ sample buffer, and both were boiled for $5 \mathrm{~min}$ before electrophoresis.

DNA transfection. DNA transfection was performed using the Lipofectamine 2000 transfection reagent (Invitrogen) according to the manufacturer's instructions. Cells were grown to $90 \%$ confluence in a six-well plate containing $1 \mathrm{ml}$ of MEM- $\alpha$ with $10 \%$ FBS without antibiotics. Two micrograms of DNA and $5 \mu$ l of Lipofectamine reagent were combined in a total volume of $250 \mu \mathrm{l}$ of Opti-MEM media (Invitrogen) and, after 20 min incubation, added to the cells. Cells were trypsinized for cell migration assays or lysed for protein after $48-72 \mathrm{~h}$.

siRNA transfection. For knockdown of ADAM-10 and N-cadherin, siRNA was purchased as a pool of siRNA sequences from Dharmacon and transfected into GBM cells using the Amaxa Nucleofector (Amaxa). Cells were trypsinized and diluted to a concentration of $2 \times 10^{6} / 100 \mu \mathrm{l}$ in Amaxa buffer V containing 200-600 nM siRNA, and then electroporated using the A23 pulse program and immediately resuspended in complete media. After $48 \mathrm{~h}$, cells were lysed and target expression was determined by Western blot. Scramble sequence siRNA was used as a control.

shRNA transfection. U-1242 MG cells were transduced with viral particles containing one of four independent shRNA sequences targeting PKC- $\alpha$, and after $7 \mathrm{~d}$ of selection in $1 \mu \mathrm{g} / \mathrm{ml}$ puromycin, the mixed culture was screened for target expression by Western blot. Mixed cultures displaying the best knockdown were then subjected to dilution cloning. For dilution cloning, cells from the mixed cultures were plated at a density of one cell per well of a 96-well plate, and each clone was expanded and screened for target expression by Western blot.

Confocal microscopy. Cells were plated at a density of $4 \times 10^{4}$ cells/well of a six-well plate on top of sterile no. 0 glass coverslips (Thomas Scientific), and after $24 \mathrm{~h}$ were incubated overnight in MEM- $\alpha$ without serum before treatment. Confocal microscopy was performed as previously described (Amos et al., 2007). Images were captured using an Olympus IX71 laser confocal microscope with a PlanApoN $60 \times$ objective and Olympus Fluoview software, version 5.0 (Olympus).

Cell-cell adhesion assay. Wild-type or siRNA-containing GBM cells were seeded at a density of $1.5 \times 10^{5}$ cells per well for U-1242 MG cells, or $4.5 \times 10^{5}$ cells per well for U-251 MG cells. A separate group of wild-type GBM cells were grown in a $10 \mathrm{~cm}$ dish to a density of $60-70 \%$ and incubated in complete media containing $1 \mu \mathrm{Ci} / \mathrm{ml}\left[{ }^{3} \mathrm{H}\right]$ thymidine for $24 \mathrm{~h}$. The $\left[{ }^{3} \mathrm{H}\right]$ thymidine labeled cells were then trypsinized, counted, and seeded at a density of $5 \times 10^{4}$ cells per well on the monolayer of cells. After incubation at $37^{\circ} \mathrm{C}$ for $30 \mathrm{~min}$ for U-1242 MG cells, or $5 \mathrm{~min}$ for U-251 MG cells (empirically determined to be the time necessary for $\sim 50 \%$ of cells to attach), any unbound cells were washed away by rinsing twice with serum-free media. After the addition of $250 \mu \mathrm{l}$ of $1 \mathrm{M} \mathrm{NaOH}$ and incubation overnight at room temperature to ensure complete cell lysis, $250 \mu \mathrm{l}$ of $2 \mathrm{~N} \mathrm{HCl}$ was added to each well to neutralize the $\mathrm{NaOH}$, and adherent cells were quantified by measuring $\left[{ }^{3} \mathrm{H}\right]$ thymidine using a scintillation counter.

Cell migration assay. GBM cells were trypsinized and resuspended in serum-free MEM- $\alpha$ to a concentration of $3.3 \times 10^{5}$ cells $/ \mathrm{ml}$. A volume of $300 \mu \mathrm{l}$ of the cell suspension was seeded on a polycarbonate filter containing $8 \mu \mathrm{m}$ pores (BD Biosciences) in a 24 -well plate and $500 \mu \mathrm{l}$ of medium containing $1 \%$ FBS was then added to the lower chamber. Cells were allowed to migrate for $1.5 \mathrm{~h}$ (U-1242 MG) or $2.5 \mathrm{~h}$ (U-251 MG) before staining with $0.1 \%$ crystal violet.

Cell motility assay. Coverslips in dishes (P35G-0-14-C; MatTek) were coated with $50 \mu \mathrm{g} / \mathrm{ml}$ poly-L-lysine (Sigma-Aldrich). Two hours later, the coverslip dishes were washed with MEM- $\alpha$, trypsizined cells were added at $1 \times 10^{4}$ cells per dish, and cells were allowed to grow to $\sim 40 \%$ confluency. The next day, medium was exchanged with L-15 media (Sigma-Aldrich) containing 0.3\% BSA and $0.1 \%$ glucose, and the dish was placed in a microincubator. After $1 \mathrm{~h}$, cells were imaged at $5 \mathrm{~min}$ 
intervals over $2 \mathrm{~h}$ using an inverted microscope (Zeiss Axiovert 100TV) and a digital camera. A minimum of 15 cells was tracked with SimplePCI tracking and imaging software (Compix) through the series of images to give a total curvilinear distance and velocity for each cell.

Trypan blue staining. U-1242 MG or U-251 MG cells were transfected with ADAM-10, N-cadherin, or scramble siRNA as described above. After $48 \mathrm{~h}$, cells were trypsinized and resuspended in Trypan blue (Sigma-Aldrich) according to the manufacturer's instructions. For each experiment, cells were counted three times per treatment using a hemacytometer. Viability was calculated as follows: (no. unstained cells)/(total no. of cells).

FACS analysis of viability. U-1242 MG or U-251 MG cells were transfected with ADAM-10, N-cadherin, or scramble siRNA as described above. Apoptosis was induced in control cells using a UV Stratalinker. A total of $0.2 \times 10^{6}$ cells from each condition was aliquoted into FACS tubes and washed in $300 \mu \mathrm{l}$ of Annexin binding buffer (10 mM HEPES, $140 \mathrm{~mm} \mathrm{NaCl}, 2.5 \mathrm{~mm} \mathrm{CaCl}_{2}, \mathrm{pH}$ 7.4). Cells were then resuspended in 100 $\mu \mathrm{l}$ of Annexin binding buffer with $5 \mu \mathrm{l}$ of PE-Annexin $\mathrm{V}$ and incubated at $37^{\circ} \mathrm{C}$ and $5 \% \mathrm{CO}_{2}$ for $15 \mathrm{~min}$. After the incubation, $400 \mu \mathrm{l}$ of Annexin binding buffer was added to each sample along with 50 ng of 7-AAD (7-amino actinomycin D) (BD Biosciences). Cells were immediately analyzed on a CyAN ADP flow cytometer (Dako), and the resulting data were evaluated using FlowJo software (Tree Star).

\section{Results}

\section{GBM cells cleave $\mathrm{N}$-cadherin in a PKC-inducible manner}

PKCs are involved in the promotion of GBM tumorigenesis, as well as the initiation of $\mathrm{N}$-cadherin cleavage in fibroblasts (Reiss et al., 2005). For this reason, we first determined the responsiveness of N-cadherin to PMA-induced cleavage in U-1242 MG and U-251 MG cells. To study the amount of N-cadherin ectodomain cleavage occurring over time, cells were pretreated with the $\gamma$-secretase inhibitor L-685,458, thus preventing the additional processing of CTF1 by presenilin-1 to yield the cytoplasmic CTF2 cleavage product. Western blotting was then used to detect fulllength $\mathrm{N}$-cadherin and CTF1. Cleavage of N-cadherin, as evidenced by production of the CTF1 fragment of $\mathrm{N}$-cadherin, was detected at baseline in these cells, and treatment with PMA increased $\mathrm{N}$-cadherin cleavage in a time-dependent manner in both cell lines (Fig. 1A). Furthermore, the observed PMA-induced cleavage of $\mathrm{N}$-cadherin was blocked by pretreatment for $1 \mathrm{~h}$ with the broad-spectrum PKC inhibitor bisindolylmaleimide (BIM) (Fig. 1A), indicating that this process is PKC dependent.

To investigate the prevalence of PMA-induced $\mathrm{N}$-cadherin cleavage in human gliomas, we analyzed two primary GBM cell lines derived from patient tumor tissue: GBM\#6 and GBM\#8 (Sarkaria et al., 2006). N-Cadherin cleavage was evident in both GBM\#6 and GBM\#8 at baseline, at even higher levels than in the established cell lines U-1242 MG and U-251 MG (Fig. $1 B$ ). In addition, treatment with PMA for $6 \mathrm{~h}$ increased $\mathrm{N}$-cadherin cleavage in these primary cultures, providing additional evidence that $\mathrm{N}$-cadherin is cleaved in a PKC-inducible manner in human GBMs.

\section{GBMs have increased N-cadherin cleavage compared with non-neoplastic brain}

Since PMA increased N-cadherin cleavage in GBM cells, we hypothesized that GBM cells may differentially cleave N-cadherin compared with non-neoplastic cells. To test this hypothesis, total protein was extracted from U-1242 MG cells, U-251 MG cells, and a culture of NHAs. When compared with NHAs, both GBM cell lines were found to have significantly higher levels of cleaved $\mathrm{N}$-cadherin, both at baseline and after stimulation with PMA (Fig. 2A).

Although these NHAs are the closest cell line approximation
A

U-1242

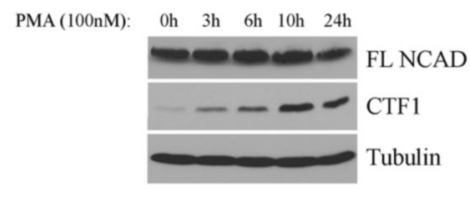

+ BIM

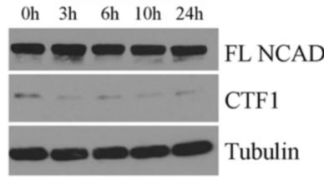

U-251
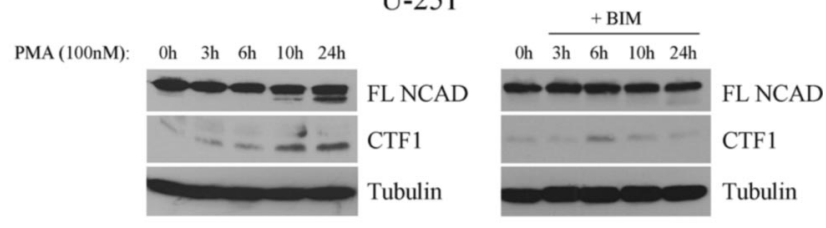

B

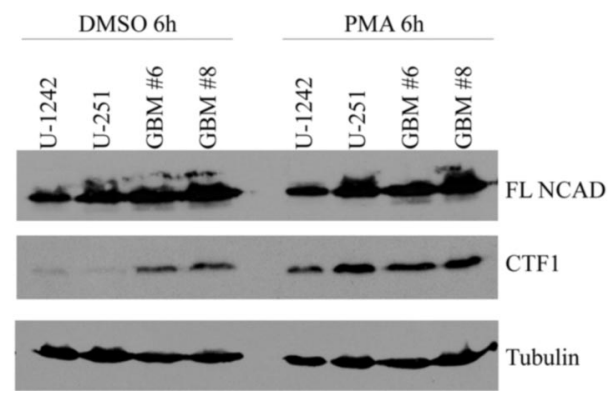

Figure 1. N-Cadherin cleavage is induced by PMA in GBM cells. A, U-1242 MG and U-251 MG cells were serum starved and incubated with the $\gamma$-secretase inhibitor L-685,458 $(5 \mu \mathrm{m}) 25 \mathrm{~h}$ before lysis, followed by treatment with PMA (100 nM) at 0, 3, 6, 10, or $24 \mathrm{~h}$ before lysis. An additional group of cells was treated with the broad-spectrum PKC inhibitor BIM $(1 \mu \mathrm{M}) 1 \mathrm{~h}$ before PMA at each time point. Lysates were subjected to SDS-PAGE and immunoblotted for $\mathrm{N}$-cadherin and tubulin as a loading control. FL NCAD, Full-length N-cadherin ( $\sim 135 \mathrm{kDa})$; CTF1, C-terminal fragment 1 ( $\sim 40 \mathrm{kDa}$ ). B, U-1242 MG cells, U-251 MG cells, and primary GBM cultures 6 and 8 were treated with L-685,458 $(5 \mu \mathrm{m})$ for $1 \mathrm{~h}$ before $6 \mathrm{~h}$ treatment with PMA (100 $\mathrm{nm)}$ or DMSO vehicle control. Lysates were immunoblotted as in $\boldsymbol{A}$.

to in vivo astrocytes, they proliferate at a 5- to 10 -fold lower rate than glioma cell lines and may have variable gene expression patterns when compared with adult astrocytes in vivo. Therefore, to validate the relevance of these findings in human specimens, we assessed $\mathrm{N}$-cadherin cleavage in a limited number of available frozen non-neoplastic temporal lobe specimens and GBM specimens without the use of a $\gamma$-secretase inhibitor. Membrane fractions were purified to further enrich the lysates in $\mathrm{N}$-cadherin and aid in visualization of the CTF1 cleavage product. Although full-length $\mathrm{N}$-cadherin was detected in all temporal lobe and GBM specimens, cleaved N-cadherin was present at very low or undetectable levels in the temporal lobe specimens (Fig. 2 B). In contrast, cleaved $\mathrm{N}$-cadherin was detected in both GBM specimens analyzed, at levels comparable with that seen in membrane fractions from U-1242 MG cells and the primary GBM cell line GBM\#6. Together, these data suggest that cleaved N-cadherin is present in human GBMs and may be produced at higher levels than in non-neoplastic brain.

\section{$\mathrm{N}$-cadherin cleavage in GBM cells requires ADAM-10}

To further study the cleavage of $\mathrm{N}$-cadherin, we next determined which MMPs or ADAMs are responsible for cleaving $\mathrm{N}$-cadherin in GBM cells. We used pharmacological inhibitors directed against several proteases that have previously been implicated in cleavage of cadherins, including ADAM-10, ADAM-17, MMP-14 (MT1-MMP), and MMP-9 (Maretzky et al., 2005; Reiss et al., 2005; Bech-Serra et al., 2006; Covington et al., 2006; Symowicz et 
A

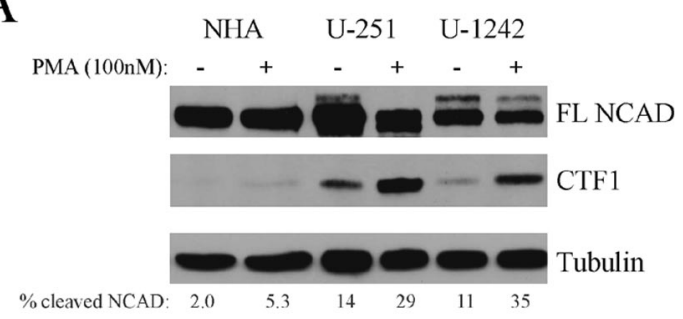

B

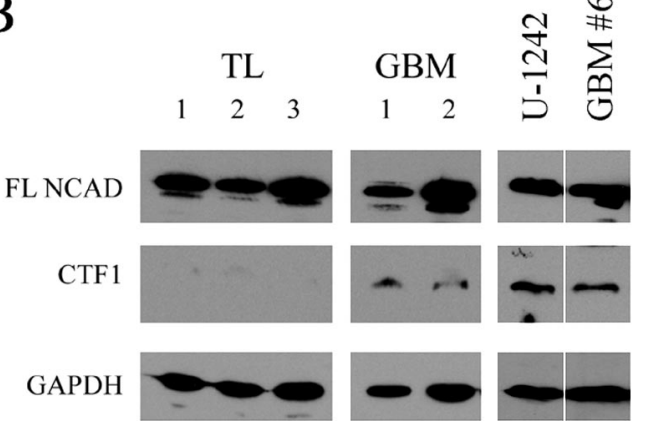

Figure 2. N-Cadherin cleavage is increased in GBM cells. A, U-1242 MG cells, U-251 MG cells, and NHAs were treated with the $\gamma$-secretase inhibitor L-685,458 $(5 \mu \mathrm{M})$ for $1 \mathrm{~h}$ before $24 \mathrm{~h}$ treatment with PMA (100 nM) or DMSO vehicle control. Lysates were subjected to SDS-PAGE and immunoblotted for $\mathrm{N}$-cadherin and tubulin. Percentage $\mathrm{N}$-cadherin cleavage was calculated by densitometry using the following formula: (CTF1)/(CTF1 + FL). Results are representative of three independent experiments. $\boldsymbol{B}$, Human non-neoplastic temporal lobe (TL) tissue specimens and human GBM tissue specimens were homogenized and lysed for protein in the absence of $\gamma$-secretase inhibitor. U-1242 MG cells and primary culture GBM\#6 were lysed in the same manner for comparison. Crude membrane fractions were then purified and analyzed for $\mathrm{N}$-cadherin cleavage by Western blot.

al., 2007). As anticipated, treatment with standard concentrations (5-20 $\mu \mathrm{M}$ ) of the broad-spectrum hydroxamate-based peptidomimetic MMP/ADAM inhibitor GM6001 (Grobelny et al., 1992) completely abrogated N-cadherin cleavage in both U-1242 MG and U-251 MG cells (Fig. 3A). The SB-3CT $p$ MS compound, a more selective inhibitor of MMP-9 and MMP-14, as well as MMP-2 and MMP-3 (Ikejiri et al., 2005), was unable to inhibit $\mathrm{N}$-cadherin cleavage in GBM cells at concentrations of $50 \mathrm{~nm}$ to 5 $\mu \mathrm{M}$ (supplemental Fig. S1, available at www.jneurosci.org as supplemental material). However, treatment with the selective ADAM-10 and ADAM-17 inhibitor GW280264X (Hundhausen et al., 2003) decreased $\mathrm{N}$-cadherin cleavage both in the presence and absence of PMA (Fig. 3B). Furthermore, the ADAM-10specific inhibitor GI254023X $(2 \mu \mathrm{M})$, which has been reported to minimally affect ADAM-17 activity (Hundhausen et al., 2003), completely blocked $\mathrm{N}$-cadherin cleavage in unstimulated and PMA-treated cells (Fig. 3B), thus indicating that ADAM-10 is the major protease involved in both the basal and PMA-stimulated cleavage of N-cadherin in GBM cells.

To establish a direct role for ADAM-10 in mediating $\mathrm{N}$-cadherin cleavage in GBM cells, U-1242 MG and U-251 MG cells were transfected with ADAM-10 siRNA. The lowest effective concentration of four pooled sequences of ADAM-10 siRNA was determined to be $400 \mathrm{~nm}$ for both cell lines (Fig. 3C), and transfection with this siRNA markedly decreased $\mathrm{N}$-cadherin cleavage (Fig. 3D). This further implicates ADAM-10 as a major mediator of $\mathrm{N}$-cadherin posttranslational cleavage in GBM cells.

\section{PKC activity induces ADAM-10 membrane translocation}

Our results demonstrated that PKC-induced N-cadherin cleavage requires ADAM-10 (Fig. 3). Although ADAM-10 has not
A

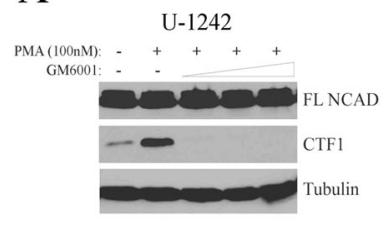

B
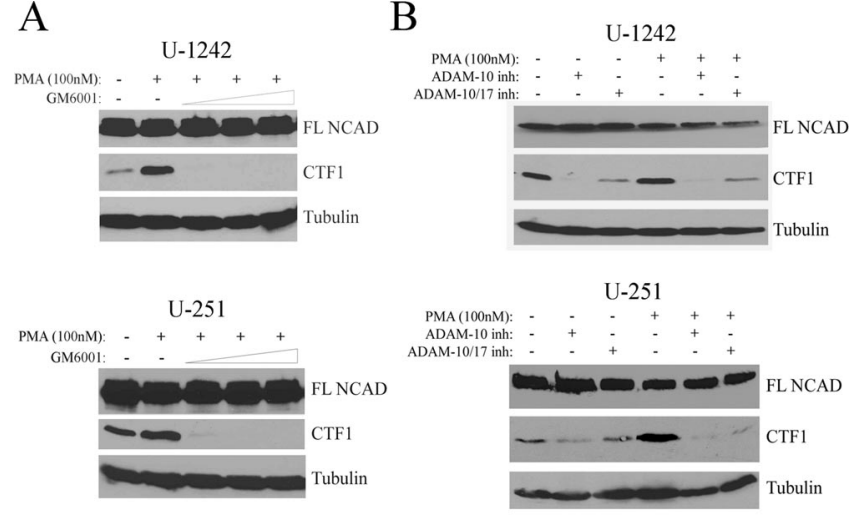

C

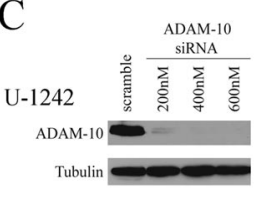

$\mathrm{D}$

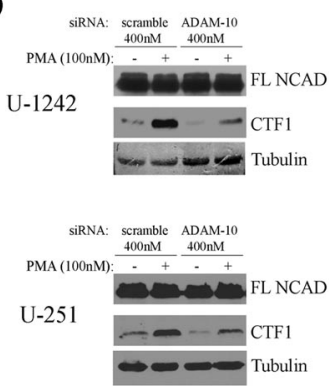

Figure 3. $\mathrm{N}$-Cadherin cleavage in GBM cells requires ADAM-10. A, U-1242 MG and U-251 MG cells were serum starved and treated with PMA or DMSO for $6 \mathrm{~h}$ after $1 \mathrm{~h}$ pretreatment with $\mathrm{L}-685,458(5 \mu \mathrm{M})$ and the MMP inhibitor GM6001 in concentrations of $0,5,10$, and $20 \mu \mathrm{M}$. Lysates were then analyzed for $\mathrm{N}$-cadherin cleavage by Western blot. $\boldsymbol{B}$, Cells were serum starved and treated as in $A$, except that the ADAM-10 and ADAM-17 inhibitor GW280264X (2 $\mu \mathrm{M})$ and ADAM-10 specific inhibitor GI254023X (2 $\mu \mathrm{M})$ were used in place of GM6001. C, U-1242 MG and U-251 MG cells were electroporated with ADAM-10 siRNA (200-600 nM) and after $48 \mathrm{~h}$ were immunoblotted for ADAM-10 to determine the optimal concentration for silencing. D, After electroporation with $400 \mathrm{~nm}$ scramble siRNA or ADAM-10 siRNA, U-1242 MG and $\mathrm{U}-251 \mathrm{MG}$ cells were treated with $\mathrm{L}-685,458(5 \mu \mathrm{M})$ for $1 \mathrm{~h}$ before $6 \mathrm{~h}$ treatment with PMA or DMSO. Lysates were analyzed for $\mathrm{N}$-cadherin cleavage by Western blot.

been shown to be directly regulated by PKCs, previous reports have suggested that PKC activation may cause alterations in subcellular localization of other ADAMs (Sundberg et al., 2004). To determine whether ADAM-10 changes its subcellular localization in response to $\mathrm{PKC}$ activation, $\mathrm{U}-1242 \mathrm{MG}$ cells were treated with PMA for $0,10,30$, or $60 \mathrm{~min}$ and ADAM-10 localization was analyzed using laser confocal microscopy. Untreated cells showed homogeneous localization of ADAM-10 throughout the nucleus and cytoplasm (Fig. 4A). On treatment with PMA, ADAM-10 immunoreactivity increased at the plasma membrane (Fig. 4A).

To confirm this finding, U-1242 MG cells were fractionated and both cytosolic and membrane proteins were analyzed by Western blot. p38 and EGFR were used as cytoplasmic and membrane controls, respectively, to ensure appropriate fractionation (data not shown). In support of the confocal microscopy data, treatment with PMA increased the proportion of ADAM-10 in the membrane fraction over time, as evidenced by the increasing membrane/cytosolic ratio of ADAM-10 (Fig. 4B).

We next hypothesized that this change in localization may promote the activity of ADAM-10 by allowing it to access its substrate N-cadherin. U-1242 MG cells were treated with PMA or vehicle control for $30 \mathrm{~min}$ and fractionated before Western blot analysis. In contrast to the change in localization observed with ADAM-10, full-length and cleaved N-cadherin were observed only in the membrane fraction, both before and after PMA treat- 
A

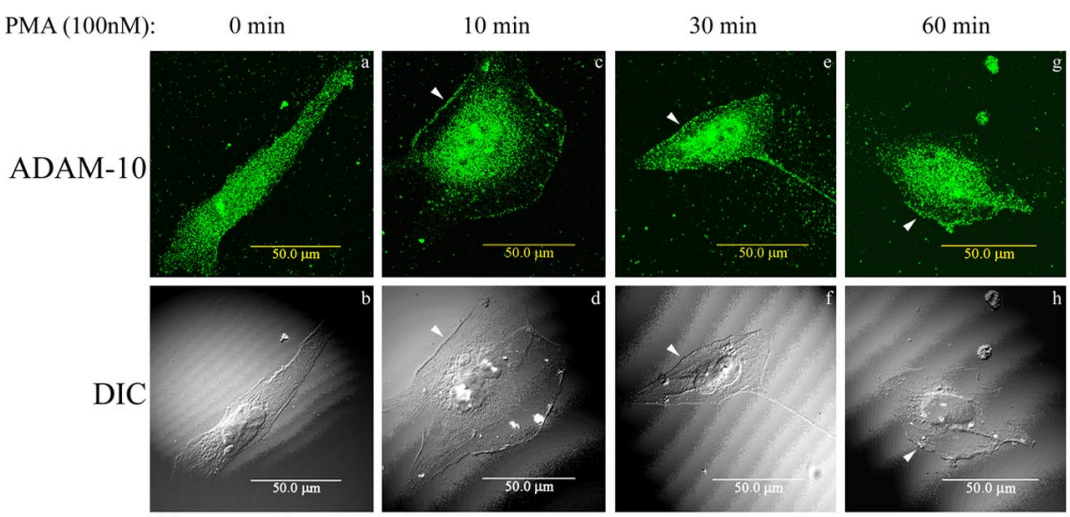

B
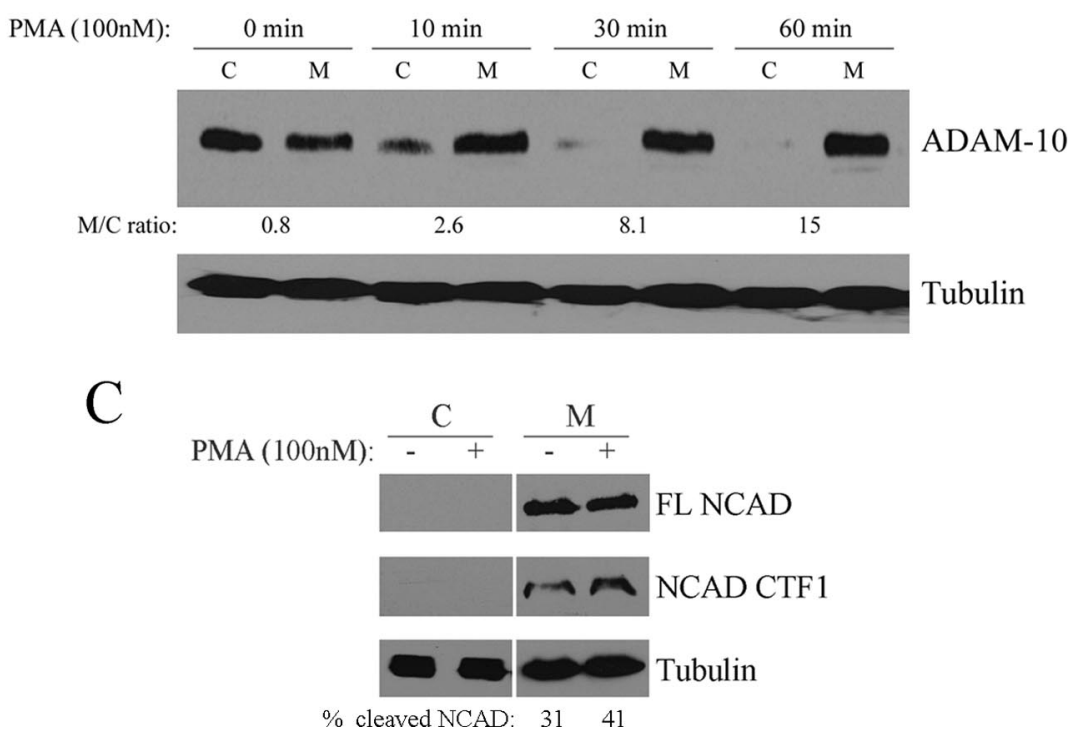

Figure 4. PKC activity induces ADAM-10 membrane translocation. $\boldsymbol{A}$, After overnight serum starvation and treatment with PMA for $0 \mathrm{~min}(\boldsymbol{a}, \boldsymbol{b}), 10 \mathrm{~min}(\boldsymbol{c}, \boldsymbol{d}), 30 \mathrm{~min}(\boldsymbol{e}, \boldsymbol{f})$, or $60 \mathrm{~min}(\boldsymbol{g}, \boldsymbol{h})$, cells were prepared for confocal microscopy by incubating with primary antibody to ADAM-10, followed by incubation with Alexa Fluor 488 goat anti-mouse secondary antibody. The arrowheads highlight prominent regions of the cell membrane in the focal plane in which ADAM-10 is localized. $\boldsymbol{B}, \mathrm{U}-1242$ MG cells were treated with PMA, and the membrane and cytosolic fractions were analyzed by Western blot. An equal proportion of membrane (M) and cytosolic $(C)$ protein was loaded for each treatment, and the $M / C$ ratio, a measure of ADAM-10 translocation, was calculated by densitometry. Results are representative of three independent experiments. C, U-1242 MG cells were treated with PMA or DMSO vehicle control for 30 min and fractionated as in $\boldsymbol{B}$. Lysates were immunoblotted for $\mathrm{N}$-cadherin and tubulin. $\mathrm{N}$-Cadherin cleavage was quantified by densitometry and normalized to tubulin. Percentage cleaved $\mathrm{N}$-cadherin was determined as follows: [CTF1/(CTF1 + FL)]. Values shown are means of four independent experiments.

ment (Fig. 4C). After PMA treatment, ADAM-10 became colocalized with its substrate $\mathrm{N}$-cadherin at the membrane (supplemental Fig. S2, available at www.jneurosci.org as supplemental material), and the amount of CTF1 present in the membraneenriched fraction subsequently increased, from $31 \pm 4.6$ to $41 \pm$ $3.5 \%$ (mean \pm SEM; $N=4 ; p<0.01$, paired $t$ test). Together, these findings support the hypothesis that translocation of ADAM-10 increases its interaction with $\mathrm{N}$-cadherin and promotes $\mathrm{N}$-cadherin cleavage.

\section{$\mathrm{N}$-cadherin cleavage and ADAM-10 translocation require $\mathrm{PKC}-\boldsymbol{\alpha}$}

To investigate which PKC isozyme(s) were mediating this cleavage event, U-1242 MG and U-251 MG cells were treated for $1 \mathrm{~h}$ with either the broad-spectrum PKC inhibitor bisindolylmaleimide $(1 \mu \mathrm{M})$ or the PKC- $\alpha$ and PKC- $\beta \mathrm{I} / \mathrm{II}$ inhibitor Gö6976 (10 $\mu \mathrm{M})$, after which cells were stimulated with PMA for $6 \mathrm{~h}$. Each of these inhibitors attenuated PMA-induced $\mathrm{N}$-cadherin cleavage in both U-1242 MG and U-251 MG cells (Fig. 5A). Since Gö6976 blocks the activity of two classical PKC isozymes ( $\alpha$ and $\beta$ ), we also used hispidin $(10 \mu \mathrm{M})$ to specifically block PKC- $\beta$. Pretreatment with hispidin had no effect on $\mathrm{N}$-cadherin cleavage, thus verifying that PKC- $\alpha$, and not PKC- $\beta$, is involved in mediating $\mathrm{N}$-cadherin cleavage in GBM cells (Fig. 5A).

To confirm the direct role of PKC- $\alpha$ in regulating $\mathrm{N}$-cadherin cleavage, we infected U-1242 MG cells with lentiviral particles containing shRNA directed against PKC- $\alpha$. Two stable knockdown clones were analyzed by Western blot for expression of PKC- $\alpha$, the classical isozyme PKC- $\gamma$ and the novel isozyme PKC- $\delta$ to ensure that the knockdown of PKC- $\alpha$ was effective and specific (Fig. 5B). Compared with U-1242 MG cells containing nontarget shRNA, the two PKC- $\alpha$ knockdown clones demonstrated reduced $\mathrm{N}$-cadherin cleavage (Fig. 5C), thus confirming the results obtained using PKC isozyme-specific pharmacological inhibitors.

We next investigated the mechanism by which PKC- $\alpha$ may contribute to $\mathrm{N}$-cadherin cleavage. Others have suggested that $\mathrm{PKC}$ isozymes such as $\mathrm{PKC}-\delta$ and $-\varepsilon$ may regulate localization of ADAM-9 and -12 , respectively (Izumi et al., 1998; Sundberg et al., 2004). We therefore hypothesized that PKC- $\alpha$ could increase $\mathrm{N}$-cadherin cleavage by promoting PMA-induced membrane translocation of ADAM-10 (Fig. 4A,B). Immunofluorescence staining of vehicle-treated U-1242 MG cells indicated whole-cell localization of endogenous ADAM-10, with no focal membrane staining (Fig. 6A). After treatment with PMA for $60 \mathrm{~min}$, a proportion of the cellular pool of ADAM-10 was visible at the cell membrane, an effect that was reduced by pretreatment with Gö6976 (Fig. 6A), suggesting that PKC- $\alpha$ kinase activity is required for ADAM-10 translocation after PMA treatment.

To verify the confocal microscopy results, U-1242 MG cells were fractionated and analyzed for ADAM-10 expression. As expected, inhibition of PKC- $\alpha$ activity by pretreatment with Gö6976 significantly impaired the membrane translocation of ADAM-10 (Fig. 6B), reducing the PMA-mediated increase in ADAM-10 membrane/cytosol ratio by an average of 70\% (Fig. 6C). To confirm that the Gö6976-induced shift of ADAM-10 away from the membrane was attributable to decreased translocation, and not caused by an increase in ADAM-10 degradation, cells were treated with Gö6976 and assessed for total ADAM-10 levels. Gö6976 treatment did not cause any detectable degradation of ADAM-10 (supplemental Fig. S3 A, B, available at www. jneurosci.org as supplemental material). Likewise, treatment with either the lysosome inhibitor chloroquine or the proteasome inhibitor MG-132 was unable to block the Gö6976-induced shift 
of ADAM-10 toward the cytosolic fraction (supplemental Fig. S3C, available at www.jneurosci.org as supplemental material). This further suggests that this shift is likely attributable to altered translocation of ADAM-10, rather than an effect of Gö6976 on the degradation of ADAM-10 at the membrane. Similar fractionation and Western blot analysis revealed that cells containing PKC- $\alpha$ shRNA also demonstrated a $60-70 \%$ reduction in PMA-mediated ADAM-10 membrane translocation compared with cells containing nontarget shRNA (Fig. 6D,E). Together, these results indicate that inhibition of PKC- $\alpha$ disrupts the PMAinduced cell surface localization of ADAM-10 in GBM cells.

\section{$\mathrm{N}$-cadherin cleavage promotes GBM cell migration}

Although the role of $\mathrm{N}$-cadherin cleavage in human cancer is unclear, $\mathrm{N}$-cadherin itself has been implicated in promoting migration and invasion of several tumor types. In GBMs, however, the function of $\mathrm{N}$-cadherin and its posttranslational cleavage has not been fully elucidated. Therefore, we first investigated the role of $\mathrm{N}$-cadherin in GBM cells by using siRNA to silence expression of $\mathrm{N}$-cadherin and its cleaved forms. Although $\mathrm{N}$-cadherin is expressed at high levels in these cells, we observed a 50\% knockdown of the full-length form of $\mathrm{N}$-cadherin after transfection with $600 \mathrm{nM}$ of four pooled siRNA sequences in U-1242 MG cells and $400 \mathrm{~nm}$ in U-251 MG cells (Fig. 7A).

In a rapid cell-cell adhesion assay, we observed no difference in the number of adherent cells between scramble control and N-cadherin siRNA transfected cells (Fig. $7 B$ ). In contrast, the same concentrations of $\mathrm{N}$-cadherin siRNA reduced Transwell migration of U-1242 MG cells by $35 \%$, and U-251 MG cells by $60 \%$ (Fig. 7C). To confirm the inhibitory effect of $\mathrm{N}$-cadherin silencing on cell migration, cells were plated on poly-L-lysine and their movement was tracked over time. In accordance with data from Transwell migration assays, U-1242 MG cells transfected with $\mathrm{N}$-cadherin siRNA demonstrated a $21 \%$ decrease in motility in this assay (supplemental Fig. S4, available at www.jneurosci. org as supplemental material). In both cell lines, the $\mathrm{N}$-cadherin siRNA had no significant effect on cell viability or apoptosis (supplemental Fig. S5, available at www.jneurosci. org as supplemental material).

These results suggest a function for $\mathrm{N}$-cadherin in regulating GBM cell migration. Because N-cadherin siRNA targets both the full-length and cleaved forms of $\mathrm{N}$-cadherin, however, these studies alone were unable to specifically discern the role of $\mathrm{N}$-cadherin cleavage. Therefore, to further test the function of $\mathrm{N}$-cadherin cleavage, we performed adhesion and migration assays after transfection of GBM cells with siRNA directed against ADAM-10, which we established can reduce $\mathrm{N}$-cadherin cleavage (Fig. 3D).

Depletion of ADAM-10 had no significant effect on cell-cell adhesion in either cell line (Fig. $8 \mathrm{~A}$ ). However, siRNA silencing of ADAM- 10 caused a $40 \%$ decrease in U-1242 MG cell migration and a 39\% decrease in U-251 MG cell migration (Fig. 8 B). Moreover, in accordance with the data acquired using $\mathrm{N}$-cadherin siRNA, U-1242 MG cells transfected with ADAM-10 siRNA showed a $29 \%$ reduction in motility compared with those cells containing scramble siRNA (supplemental Fig. S4, available at www.jneurosci.org as supplemental material), thus providing additional evidence that inhibition of $\mathrm{N}$-cadherin cleavage reduces GBM cell migration. In both cell lines, the ADAM-10 siRNA had no significant effect on cell viability or apoptosis (supplemental Fig. S5, available at www.jneurosci.org as supplemental material).

Because inhibition of ADAM-10 is not entirely specific for $\mathrm{N}$-cadherin cleavage, we next sought to determine the effects of selectively decreasing cleaved N-cadherin in GBM cells. We transfected U-1242 MG cells with either a wild-type form of $\mathrm{N}$-cadherin or a mutant $\mathrm{N}$-cadherin that has been mutated at its MMP/ADAM extracellular cleavage site (Uemura et al., 2006). Both of these HA-tagged proteins were expressed in our cells and the mutant form could not be effectively cleaved to produce CTF1 (Fig. 9A). In functional studies, overexpression of wildtype $\mathrm{N}$-cadherin did not significantly affect Transwell migration of U-1242 MG cells compared with cells containing empty vector 
A

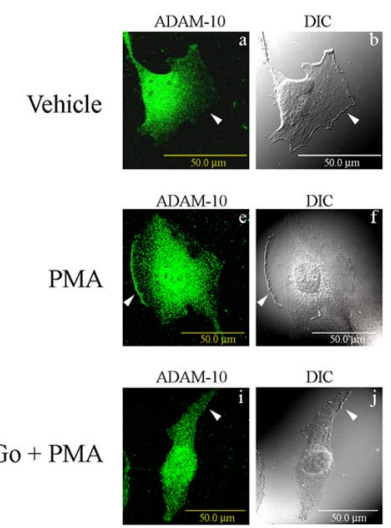

B

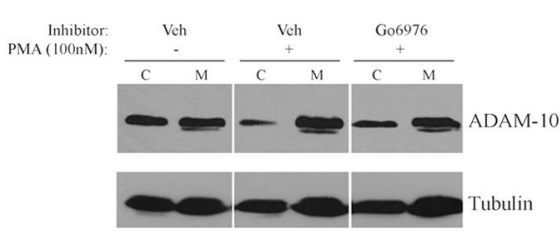

D

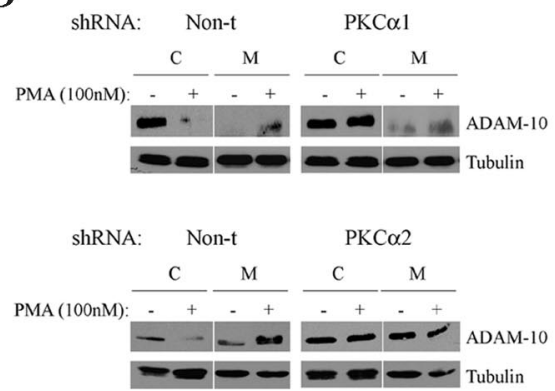

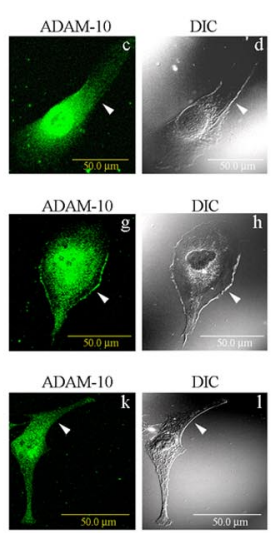

C

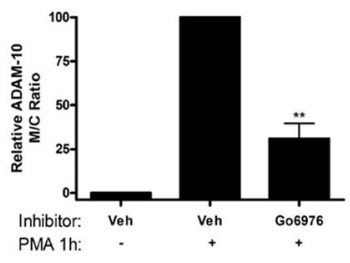

$\mathbf{E}$

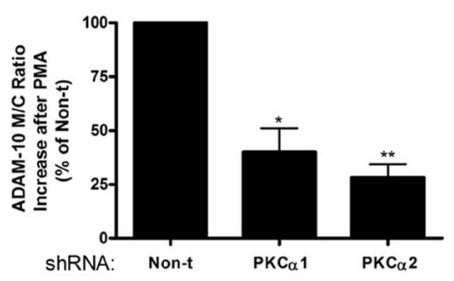

Figure 6. ADAM-10 membrane translocation requires PKC- $\alpha$. $A$, After overnight serum starvation and treatment for $1 \mathrm{~h}$ with DMSO vehicle control $(\boldsymbol{a}-\boldsymbol{d})$, PMA $(\boldsymbol{e}-\boldsymbol{h})$, or PMA after $1 \mathrm{~h}$ pretreatment with $10 \mu \mathrm{M}$ Gö6976 $(\boldsymbol{i}-\boldsymbol{I})$, cells were prepared for confocal microscopy by incubating with primary antibody to ADAM-10, followed by incubation with Alexa Fluor 488 goat antimouse secondary antibody. Two cells are shown for each treatment, which are representative of three independent experiments. The arrowheads highlight prominent regions of the cell membrane that are in the focal plane. $\boldsymbol{B}, \mathrm{U}-1242 \mathrm{MG}$ cells were treated as in $\boldsymbol{A}$ and lysed to separate membrane and cytosolic fractions. For each condition, an equal proportion of membrane (M) and cytosolic (C) protein was loaded and analyzed by Western blot for levels of ADAM-10. C, ADAM-10 expression in $\boldsymbol{B}$ was quantified by densitometry and normalized to tubulin. The ratio of membranous ADAM-10 to cytosolic ADAM-10 was calculated for each treatment. The ADAM-10 M/C ratio in vehicle-treated cells was normalized to 0 and in PMA-treated cells was normalized to 100 . The columns represent means of four independent experiments; the error bars represent SEM. ${ }^{* *} p<0.005$, paired $t$ test. $D$, Cells containing nontarget or PKC- $\alpha$ shRNA were treated with DMSO or PMA for $1 \mathrm{~h}$ and lysed to separate membrane and cytosolic fractions. For each condition, an equal proportion of membrane $(M)$ and cytosolic (C) protein was analyzed by Western blot for levels of ADAM-10. $\boldsymbol{E}, \mathrm{ADAM}-10$ expression in $\boldsymbol{D}$ was quantified by densitometry and normalized to tubulin. The ratio of membranous to cytosolic ADAM-10 was calculated for each treatment. The increase in ADAM-10 M/C ratio after PMA treatment was calculated for each cell line, and normalized to nontarget shRNA transfected control cells. The columns represent means of three independent experiments; the error bars represent SEM. ${ }^{*} p<0.05,{ }^{* *} p<0.01$, paired $t$ test.

(Fig. 9B). In contrast, cells that were transfected with the mutant form of $\mathrm{N}$-cadherin demonstrated a 30\% decrease in Transwell migration compared with control cells (Fig. 9B). These data support the results of the siRNA studies, again suggesting that GBM cells deficient in $\mathrm{N}$-cadherin cleavage have impaired migration.

Last, because it has previously been demonstrated that the extracellular $\mathrm{N}$-terminal fragment of $\mathrm{N}$-cadherin can promote cell migration and neurite outgrowth (Kim et al., 2000; Utton et al., 2001; Derycke et al., 2006), we determined whether this cleaved fragment alone was sufficient to increase GBM cell migration. To accomplish this, we treated cells with either $3 \mu \mathrm{g} / \mathrm{ml}$ recombinant chimera of the extracellular domain of human $\mathrm{N}$-cadherin fused to the $\mathrm{Fc}$ portion of human IgG, or human IgG

Fc as a control. U-1242 MG cells incubated with the N-terminal product of $\mathrm{N}$-cadherin demonstrated a $35.6 \pm 7.2 \%$ increase in migration compared with control cells (mean \pm SEM; $N=3 ; p<0.05$, paired $t$ test), thus providing additional evidence of a promigratory role for $\mathrm{N}$-cadherin cleavage.

\section{Discussion}

$\mathrm{N}$-Cadherin regulates cell adhesion and migration in a wide range of cancers including melanoma, breast, and prostate (Derycke and Bracke, 2004). Because $\mathrm{N}$-cadherin is also highly expressed in neurons and glia, several studies have attempted to characterize its expression and function in GBMs. It was first demonstrated that $\mathrm{N}$-cadherin mRNA levels correlate with glioma grade, and these data were later corroborated by microarray (Shinoura et al., 1995; Asano et al., 2004). In addition, one study has demonstrated that $\mathrm{N}$-cadherin protein levels are increased in GBMs (Utsuki et al., 2002). Others, however, have reported no difference in $\mathrm{N}$-cadherin protein expression between low- and high-grade gliomas or have shown that $\mathrm{N}$-cadherin expression inversely correlates with tumor grade in recurrent lesions (Shinoura et al., 1995; Asano et al., 2000). These findings indicate that, although $\mathrm{N}$-cadherin may participate in glioma pathogenesis, there is no consensus as to the significance of its overall expression.

In the current study, we have verified that $\mathrm{N}$-cadherin is expressed by both nonneoplastic astrocytes and GBM cells. Additionally, we have demonstrated that $\mathrm{N}$-cadherin is posttranslationally cleaved at higher levels in glioblastoma cells than in normal astrocytes and that cleaved $\mathrm{N}$-cadherin is present in human GBM specimens (Fig. 2). This finding may help to explain the seemingly conflicting data regarding the expression of $\mathrm{N}$-cadherin in glioblastomas. Modification such as posttranslational cleavage, which occurs more abundantly in neoplastic astrocytes, may confound studies examining overall protein expression. Therefore, examining the function of $\mathrm{N}$-cadherin, rather than merely its expression, may be more informative in elucidating its role in gliomagenesis.

In this study, we found that reduction of $\mathrm{N}$-cadherin and its cleavage products by siRNA was sufficient to reduce GBM cell migration (Fig. 7C). Our results are consistent with reports that $\mathrm{N}$-cadherin function is required for GBM cell invasion and that decreased $\mathrm{N}$-cadherin junctional stability, as may occur on its cleavage, can increase GBM cell migration (Kotelevets et al., 2001; Perego et al., 2002). Furthermore, we demonstrated that cleavage of N-cadherin in GBM cells is dependent on the activity of ADAM-10 (Fig. 3) and that inhibition of N-cadherin cleavage by 
A<smiles>[124In]</smiles>

SiRNA $(600 \mathrm{nM})$ :

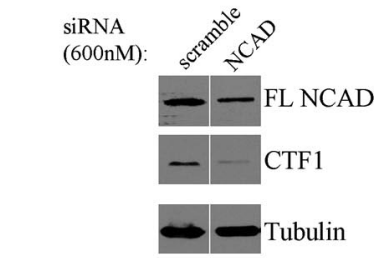

siRNA $(400 \mathrm{nM})$ :<smiles>[124In]</smiles>

(1)

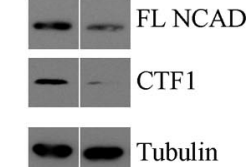

B

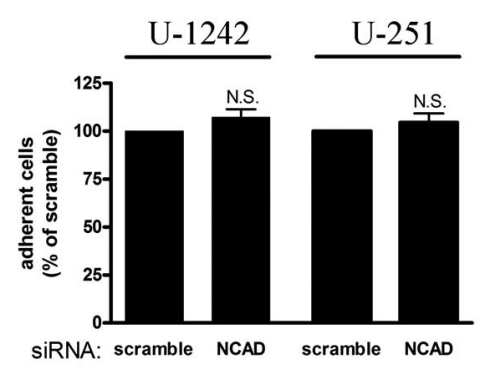

$\mathrm{C}$

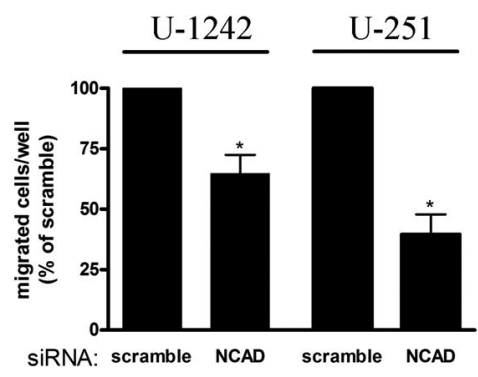

Figure 7. $\mathrm{N}$-Cadherin siRNA decreases GBM cell migration. $\boldsymbol{A}, \mathrm{U}-1242 \mathrm{MG}$ and U-251 MG cells were electroporated with 600 or $400 \mathrm{~nm}$, respectively, of scramble siRNA or N-cadherin siRNA and analyzed for $\mathrm{N}$-cadherin cleavage by Western blot, after treating with L-685,458 (5 $\mu \mathrm{m})$ for $6 \mathrm{~h} . \boldsymbol{B}$, Adhesion assays were performed by allowing $\left[{ }^{3} \mathrm{H}\right]$ thymidine-labeled $\mathrm{U}-1242 \mathrm{MG}$ and $\mathrm{U}$-251 MG cells to adhere for 30 or 5 min, respectively, to cells electroporated with $\mathrm{N}$-cadherin or scramble siRNA, before quantification by scintillation counter. The columns represent the means of three independent experiments run in triplicate; the error bars represent SEM. N.S., Not significant. C, Migration assays were performed by seeding cells onto a porous filter in a 24-well plate, allowing cells to migrate toward media with $1 \%$ FBS in the lower chamber and staining cells with $0.1 \%$ crystal violet before counting migrated cells. The columns represent the means of three to four independent experiments run in triplicate; the error bars represent SEM. ${ }^{*} p<0.05$, paired $t$ test.

siRNA-mediated silencing of ADAM-10 is sufficient to significantly impair GBM cell migration in vitro (Fig. $8 B$ ). In addition, transfection with an extracellular cleavage-site mutant $\mathrm{N}$-cadherin reduced U-1242 MG cell migration, whereas transfection with the wild-type $\mathrm{N}$-cadherin had no significant effect on migration (Fig. 9B). Because these cells naturally express high levels of $\mathrm{N}$-cadherin, it is likely that the effects of $\mathrm{N}$-cadherin overexpression are at least partially masked by this sizeable endogenous pool. Despite this limitation, the mutant N-cadherin was capable of decreasing cell migration, perhaps by introducing a population of $\mathrm{N}$-cadherin at the cell membrane that could not be cleaved or by altering the total ratio of cleaved to uncleaved $\mathrm{N}$-cadherin within the cell.

Cell migration is a dynamic process that is regulated by a complex array of signaling molecules, many of which can be activated by the EGFR, which itself is amplified or overexpressed in the majority of GBMs (Shinojima et al., 2003). Downstream of EGFR, activation of PKC by phospholipase $\mathrm{C}$ can induce cell polarization and actin remodeling, thus promoting cell migration (Pedersen et al., 2004; Larsson, 2006). Given our findings
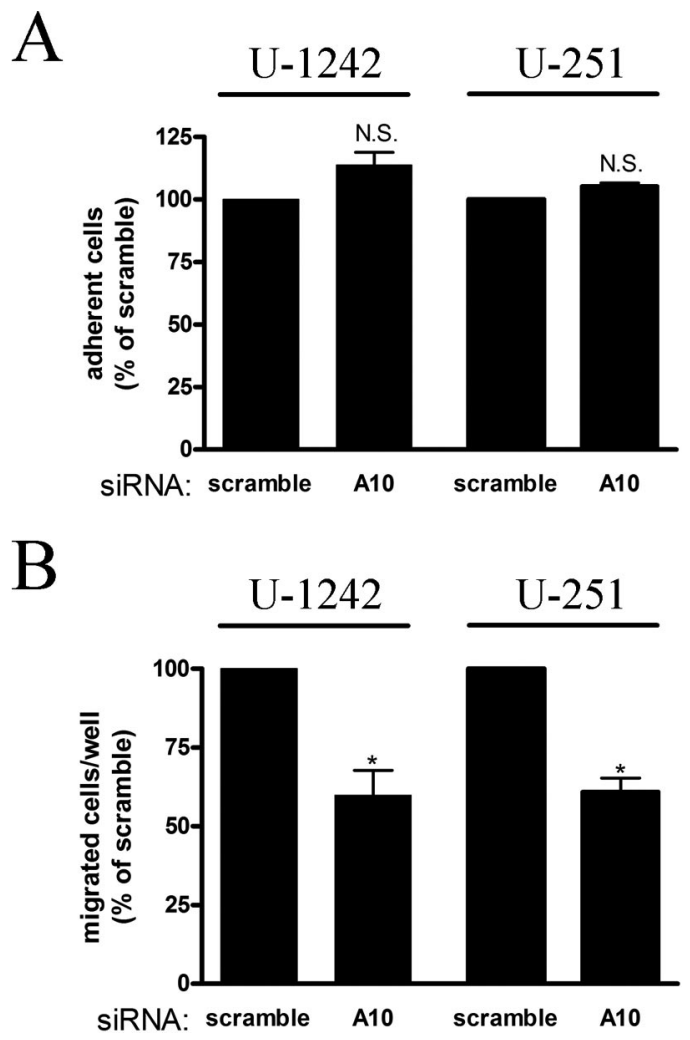

Figure 8. ADAM-10 silencing reduces GBM cell migration. $A,\left[{ }^{3} \mathrm{H}\right]$ Thymidine-labeled U-1242 MG and U-251 MG cells were allowed to adhere for 30 or 5 min, respectively, to cells electroporated with $400 \mathrm{~nm}$ ADAM-10 or scramble siRNA, before quantification by scintillation counter. The columns represent the means of three independent experiments run in triplicate; the error bars represent SEM. N.S., Not significant. B, Cells were electroporated with siRNA as in $A$, and migration assays were performed by seeding cells onto a porous filter in a 24-well plate and allowing cells to migrate toward the lower chamber. The columns represent the means of three to four independent experiments run in triplicate; the error bars represent SEM. ${ }^{*} p<$ 0.05 , paired $t$ test.

that increased PKC activity leads to the induction of $\mathrm{N}$-cadherin cleavage in GBM cells (Fig. 1), the possibility exists that the actinassociated protein $\mathrm{N}$-cadherin may be a target within the promigratory EGFR-PKC axis.

In addition to modulation of the cytoskeleton, cell migration requires concurrent detachment of cells both from one another and from their substrates via disassembly of cell-cell junctions and modification of integrin-mediated focal adhesions (Ridley et al., 2003). The few reports that have examined the effects of $\mathrm{N}$-cadherin on glioma biology have suggested that increased expression or stability of N-cadherin may inhibit tumor cell invasion by promoting cell-cell adhesion (Perego et al., 2002; Hegedüs et al., 2006). Interestingly, we did not observe any change in cell-cell adhesion after $\mathrm{N}$-cadherin silencing (Fig. 7B). Because the siRNA silencing of $\mathrm{N}$-cadherin was not complete in our studies, the residual full-length $\mathrm{N}$-cadherin on the surface of GBM cells may have been sufficient to prevent any decrease in adhesion. It is also possible that $\mathrm{N}$-cadherin is not important for the rapid formation of astrocyte-astrocyte adhesions or that other cell surface adhesion molecules can compensate for any loss in $\mathrm{N}$-cadherin. Additional studies will be necessary to fully characterize the role of $\mathrm{N}$-cadherin in mediating adhesion in glioma cells.

Metalloproteinase-mediated cleavage of cell surface proteins has previously been shown to promote cell migration and inva- 


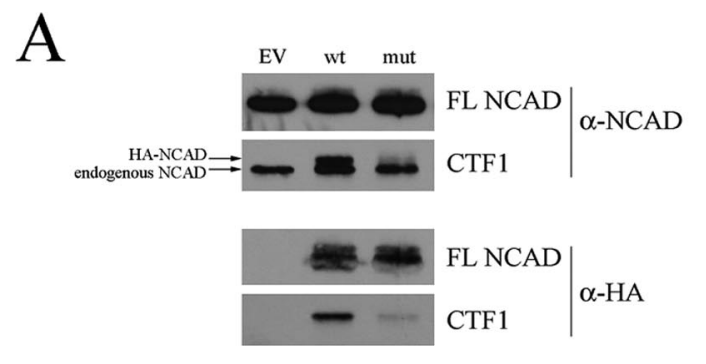

B

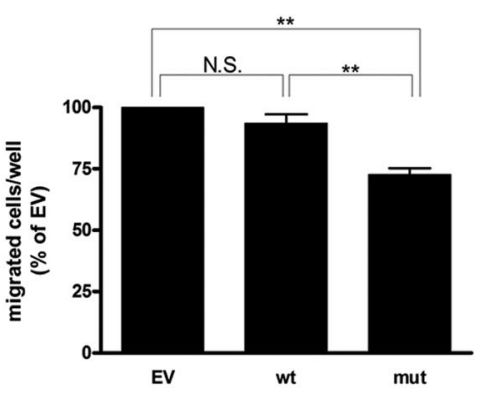

C

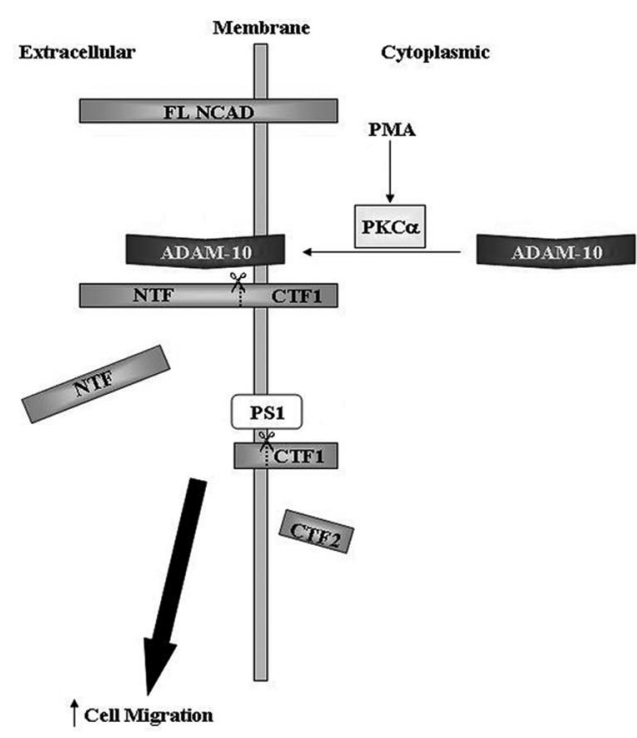

Figure 9. $\mathrm{N}$-Cadherin cleavage promotes GBM cell migration. $\boldsymbol{A}, \mathrm{U}-1242 \mathrm{MG}$ cells were transfected with pcDNA empty vector (lane 1), wild-type N-cadherin (lane 2), or mutant N-cadherin (lane 3). Cells were treated with L-685,458 (5 $\mu \mathrm{m})$ for $6 \mathrm{~h}$ before lysis and immunoblotted with anti-HA and anti-N-cadherin antibodies. $\boldsymbol{B}, \mathbf{U}-1242$ MG cells were transfected as in $\boldsymbol{A}$, seeded onto porous filters, and allowed to migrate toward media with $1 \% \mathrm{FBS}$. The columns represent the means of four independent experiments run in triplicate; the error bars represent SEM. N.S., Not significant. ${ }^{* *} p<0.005$, paired $t$ test. $C$, Working model of $\mathrm{N}$-cadherin cleavage in GBM cells.

sion in various tumor types, including gliomas. Cleavage of the hyaluronic acid receptor $\mathrm{CD} 44$, for instance, has been reported to release a migration-promoting extracellular fragment in the majority of human gliomas (Okamoto et al., 1999, 2002). Furthermore, in many solid tumors, cleavage of E-cadherin promotes cell migration and invasion by breaking cell adhesions and releasing a soluble E-cadherin fragment that can initiate proinvasive signaling cascades leading to upregulation of MMPs (Noë et al., 2001; Kuefer et al., 2003; Nawrocki-Raby et al., 2003). Based on the present study, we propose a role for the posttranslational cleavage of another cell surface protein, $\mathrm{N}$-cadherin, in regulating migration in GBM cells (Fig. 9C).

Several possible mechanisms may help to explain how $\mathrm{N}$-cadherin cleavage mediates GBM cell migration. First, in other tumor types the extracellular $\mathrm{N}$-terminal fragment of $\mathrm{N}$-cadherin promotes cell migration by interacting with and stabilizing the fibroblast growth factor receptor (Nieman et al., 1999; Williams et al., 2001; Suyama et al., 2002; Sanchez-Heras et al., 2006). These findings are consistent with our data, which show that treatment with the soluble $\mathrm{N}$-terminal product of $\mathrm{N}$-cadherin cleavage can bring about modest increases in GBM cell migration. Although this supports the hypothesis that local production of the N-terminal fragment increases cell migration, it is also possible that $\mathrm{N}$-cadherin cleavage alters cellular processes through other pathways as well. For instance, the cleaved intracellular fragment CTF2 has been shown to bind to the transcriptional regulator $\mathrm{CBP}$ [(cAMP response element-binding protein)-binding protein] and induce its proteasomal degradation (Marambaud et al., 2003). Moreover, disorganization of $\mathrm{N}$-cadherin-containing adherens junctions, as may occur on the posttranslational cleavage of $\mathrm{N}$-cadherin, is associated with increased migration in U373 glioma cells (Perego et al., 2002) and may potentially release $\mathrm{N}$-cadherin binding partners such as $\mathrm{p} 120$ catenin that have been shown to activate cell migration via Rho family GTPases (Noren et al., 2000). Future studies will be required to investigate which of these additional mechanisms may contribute to the observed effect of $\mathrm{N}$-cadherin cleavage on GBM cell migration.

Others have used animal models to study the role of $\mathrm{N}$-cadherin blockade and overexpression on tumorigenesis in xenograft models of pancreatic cancer (Shintani et al., 2008), pituitary tumors (Ezzat et al., 2006), breast cancer (Hazan et al., 2000), and melanoma (Augustine et al., 2008), yet no in vivo studies have elucidated the specific role of posttranslational cleavage of $\mathrm{N}$-cadherin in tumor progression or the role of $\mathrm{N}$-cadherin in GBM. Future experiments in our laboratory will aim to extend the findings of the present study in vivo, using a xenograft mouse model of GBM in which stable human GBM cells deficient in $\mathrm{N}$-cadherin cleavage can be introduced into the mouse brain in a Gelfoam matrix (Amos et al., 2007). Such studies will allow us to assess the effects of selective depletion of $\mathrm{N}$-cadherin cleavage in stable human GBM cell lines on glioma pathophysiology in vivo.

In addition to demonstrating a potential function for $\mathrm{N}$-cadherin cleavage in GBM cells, we have characterized its regulation by PKC isozymes. Specifically, our studies have implicated the classical isozyme PKC- $\alpha$ as necessary for both basal and PMA-mediated cleavage of $\mathrm{N}$-cadherin. A role for PKC- $\alpha$ in promoting cell surface protein cleavage events has been proposed in the context of Alzheimer's disease, in which patients have been reported to have lower levels of PKC- $\alpha$ activity, leading to decreased cleavage of APP (amyloid precursor protein) by $\alpha$-secretases such as ADAM-10 (Benussi et al., 1998). Our findings agree with the hypothesis that $\mathrm{PKC}-\alpha$ regulates both basal and phorbol ester-induced protein cleavage by ADAM-10 (Fig. 9C). In addition, we have shown that this activity of PKC- $\alpha$ may be related to its ability to regulate the subcellular localization of ADAM-10 (Fig. 6). Pharmacological inhibition of the kinase activity of PKC- $\alpha$ blocked N-cadherin cleavage and ADAM-10 membrane translocation. However, additional studies will be needed to determine the specific nature of the interaction between PKC- $\alpha$ and ADAM-10. We have been unable to detect any stable binding between PKC- $\alpha$ and ADAM-10 by coimmunopre- 
cipitation (data not shown), yet it remains possible that PKC- $\alpha$ directly phosphorylates ADAM-10 or other substrates in the secretory pathway to induce $\mathrm{N}$-cadherin cleavage.

In conclusion, our results demonstrate that PKC- $\alpha$ and ADAM-10 regulate $\mathrm{N}$-cadherin cleavage in GBM cells, and this cleavage event is involved in mediating cell migration. Together, these findings suggest that $\mathrm{N}$-cadherin, as well as its cleavage products, may need to be reevaluated as possible biomarkers or therapeutic targets in the treatment of glioblastoma multiforme.

\section{References}

Acevedo-Duncan M, Patel R, Whelan S, Bicaku E (2002) Human glioma PKC-iota and PKC-betaII phosphorylate cyclin-dependent kinase activating kinase during the cell cycle. Cell Prolif 35:23-36.

Amos S, Mut M, diPierro CG, Carpenter JE, Xiao A, Kohutek ZA, Redpath GT, Zhao Y, Wang J, Shaffrey ME, Hussaini IM (2007) Protein kinase C-alpha-mediated regulation of low-density lipoprotein receptor related protein and urokinase increases astrocytoma invasion. Cancer Res 67:10241-10251.

Asano K, Kubo O, Tajika Y, Takakura K, Suzuki S (2000) Expression of cadherin and CSF dissemination in malignant astrocytic tumors. Neurosurg Rev 23:39-44.

Asano K, Duntsch CD, Zhou Q, Weimar JD, Bordelon D, Robertson JH, Pourmotabbed T (2004) Correlation of N-cadherin expression in high grade gliomas with tissue invasion. J Neurooncol 70:3-15.

Augustine CK, Yoshimoto Y, Gupta M, Zipfel PA, Selim MA, Febbo P, Pendergast AM, Peters WP, Tyler DS (2008) Targeting N-cadherin enhances antitumor activity of cytotoxic therapies in melanoma treatment. Cancer Res 68:3777-3784.

Barami K, Lewis-Tuffin L, Anastasiadis PZ (2006) The role of cadherins and catenins in gliomagenesis. Neurosurg Focus 21:E13.

Bech-Serra JJ, Santiago-Josefat B, Esselens C, Saftig P, Baselga J, Arribas J, Canals F (2006) Proteomic identification of desmoglein 2 and activated leukocyte cell adhesion molecule as substrates of ADAM17 and ADAM10 by difference gel electrophoresis. Mol Cell Biol 26:5086-5095.

Benussi L, Govoni S, Gasparini L, Binetti G, Trabucchi M, Bianchetti A, Racchi M (1998) Specific role for protein kinase C alpha in the constitutive and regulated secretion of amyloid precursor protein in human skin fibroblasts. Neurosci Lett 240:97-101.

Cavallaro U (2004) N-cadherin as an invasion promoter: a novel target for antitumor therapy? Curr Opin Investig Drugs 5:1274-1278.

Central Brain Tumor Registry of the United States (2005) Statistical report: primary brain tumors in the United States, 1998-2002. Chicago: Central Brain Tumor Registry of the United States.

Couldwell WT, Uhm JH, Antel JP, Yong VW (1991) Enhanced protein kinase $\mathrm{C}$ activity correlates with the growth rate of malignant gliomas in vitro. Neurosurgery 29:880-886; discussion 886-887.

Covington MD, Burghardt RC, Parrish AR (2006) Ischemia-induced cleavage of cadherins in NRK cells requires MT1-MMP (MMP-14). Am J Physiol Renal Physiol 290:F43-F51.

Derycke L, Morbidelli L, Ziche M, De Wever O, Bracke M, Van Aken E (2006) Soluble N-cadherin fragment promotes angiogenesis. Clin Exp Metastasis 23:187-201.

Derycke LD, Bracke ME (2004) N-cadherin in the spotlight of cell-cell adhesion, differentiation, embryogenesis, invasion and signalling. Int J Dev Biol 48:463-476.

Ezzat S, Zheng L, Winer D, Asa SL (2006) Targeting N-cadherin through fibroblast growth factor receptor-4: distinct pathogenetic and therapeutic implications. Mol Endocrinol 20:2965-2975.

Grobelny D, Poncz L, Galardy RE (1992) Inhibition of human skin fibroblast collagenase, thermolysin, and Pseudomonas aeruginosa elastase by peptide hydroxamic acids. Biochemistry 31:7152-7154.

Hatta K, Takagi S, Fujisawa H, Takeichi M (1987) Spatial and temporal expression pattern of $\mathrm{N}$-cadherin cell adhesion molecules correlated with morphogenetic processes of chicken embryos. Dev Biol 120:215-227.

Hazan RB, Phillips GR, Qiao RF, Norton L, Aaronson SA (2000) Exogenous expression of $\mathrm{N}$-cadherin in breast cancer cells induces cell migration, invasion, and metastasis. J Cell Biol 148:779-790.

Hegedüs B, Marga F, Jakab K, Sharpe-Timms KL, Forgacs G (2006) The interplay of cell-cell and cell-matrix interactions in the invasive properties of brain tumors. Biophys J 91:2708-2716.
Hundhausen C, Misztela D, Berkhout TA, Broadway N, Saftig P, Reiss K, Hartmann D, Fahrenholz F, Postina R, Matthews V, Kallen KJ, Rose-John S, Ludwig A (2003) The disintegrin-like metalloproteinase ADAM10 is involved in constitutive cleavage of CX3CL1 (fractalkine) and regulates CX3CL1-mediated cell-cell adhesion. Blood 102:1186-1195.

Huovila AP, Turner AJ, Pelto-Huikko M, Kärkkäinen I, Ortiz RM (2005) Shedding light on ADAM metalloproteinases. Trends Biochem Sci 30:413-422.

Hussaini IM, Karns LR, Vinton G, Carpenter JE, Redpath GT, Sando JJ, VandenBerg SR (2000) Phorbol 12-myristate 13-acetate induces protein kinase $\mathrm{C} \eta$-specific proliferative response in astrocytic tumor cells J Biol Chem 275:22348-22354.

Ikejiri M, Bernardo MM, Bonfil RD, Toth M, Chang M, Fridman R, Mobashery S (2005) Potent mechanism-based inhibitors for matrix metalloproteinases. J Biol Chem 280:33992-34002.

Izumi Y, Hirata M, Hasuwa H, Iwamoto R, Umata T, Miyado K, Tamai Y, Kurisaki T, Sehara-Fujisawa A, Ohno S, Mekada E (1998) A metalloprotease-disintegrin, MDC9/meltrin-gamma/ADAM9 and PKCdelta are involved in TPA-induced ectodomain shedding of membraneanchored heparin-binding EGF-like growth factor. EMBO J 17:7260-7272.

Kim JB, Islam S, Kim YJ, Prudoff RS, Sass KM, Wheelock MJ, Johnson KR (2000) N-Cadherin extracellular repeat 4 mediates epithelial to mesenchymal transition and increased motility. J Cell Biol 151:1193-1206.

Koivunen J, Aaltonen V, Peltonen J (2006) Protein kinase C (PKC) family in cancer progression. Cancer Lett 235:1-10.

Kotelevets L, van Hengel J, Bruyneel E, Mareel M, van Roy F, Chastre E (2001) The lipid phosphatase activity of PTEN is critical for stabilizing intercellular junctions and reverting invasiveness. J Cell Biol 155:1129-1135.

Kuefer R, Hofer MD, Gschwend JE, Pienta KJ, Sanda MG, Chinnaiyan AM, Rubin MA, Day ML (2003) The role of an $80 \mathrm{kDa}$ fragment of E-cadherin in the metastatic progression of prostate cancer. Clin Cancer Res 9:6447-6452.

Lacroix M, Abi-Said D, Fourney DR, Gokaslan ZL, Shi W, DeMonte F, Lang FF, McCutcheon IE, Hassenbusch SJ, Holland E, Hess K, Michael C, Miller D, Sawaya R (2001) A multivariate analysis of 416 patients with glioblastoma multiforme: prognosis, extent of resection, and survival. J Neurosurg 95:190-198.

Larsson C (2006) Protein kinase C and the regulation of the actin cytoskeleton. Cell Signal 18:276-284.

Marambaud P, Wen PH, Dutt A, Shioi J, Takashima A, Siman R, Robakis NK (2003) A CBP binding transcriptional repressor produced by the PS1/ epsilon-cleavage of N-cadherin is inhibited by PS1 FAD mutations. Cell 114:635-645.

Maretzky T, Reiss K, Ludwig A, Buchholz J, Scholz F, Proksch E, de Strooper B, Hartmann D, Saftig P (2005) ADAM10 mediates E-cadherin shedding and regulates epithelial cell-cell adhesion, migration, and betacatenin translocation. Proc Natl Acad Sci U S A 102:9182-9187.

Nakashima S (2002) Protein kinase C alpha (PKC alpha): regulation and biological function. J Biochem (Tokyo) 132:669-675.

Nawrocki-Raby B, Gilles C, Polette M, Bruyneel E, Laronze JY, Bonnet N, Foidart JM, Mareel M, Birembaut P (2003) Upregulation of MMPs by soluble E-cadherin in human lung tumor cells. Int J Cancer 105:790-795.

Nieman MT, Prudoff RS, Johnson KR, Wheelock MJ (1999) N-cadherin promotes motility in human breast cancer cells regardless of their E-cadherin expression. J Cell Biol 147:631-644.

Noë V, Fingleton B, Jacobs K, Crawford HC, Vermeulen S, Steelant W, Bruyneel E, Matrisian LM, Mareel M (2001) Release of an invasion promoter E-cadherin fragment by matrilysin and stromelysin-1. J Cell Sci 114:111-118.

Noren NK, Liu BP, Burridge K, Kreft B (2000) p120 catenin regulates the actin cytoskeleton via Rho family GTPases. J Cell Biol 150:567-580.

Okamoto I, Kawano Y, Tsuiki H, Sasaki J, Nakao M, Matsumoto M, Suga M, Ando M, Nakajima M, Saya H (1999) CD44 cleavage induced by a membrane-associated metalloprotease plays a critical role in tumor cell migration. Oncogene 18:1435-1446.

Okamoto I, Tsuiki H, Kenyon LC, Godwin AK, Emlet DR, Holgado-Madruga M, Lanham IS, Joynes CJ, Vo KT, Guha A, Matsumoto M, Ushio Y, Saya H, Wong AJ (2002) Proteolytic cleavage of the CD44 adhesion molecule in multiple human tumors. Am J Pathol 160:441-447.

Paradies NE, Grunwald GB (1993) Purification and characterization of 
NCAD90, a soluble endogenous form of N-cadherin, which is generated by proteolysis during retinal development and retains adhesive and neurite-promoting function. J Neurosci Res 36:33-45.

Pedersen MW, Tkach V, Pedersen N, Berezin V, Poulsen HS (2004) Expression of a naturally occurring constitutively active variant of the epidermal growth factor receptor in mouse fibroblasts increases motility. Int J Cancer 108:643-653.

Perego C, Vanoni C, Massari S, Raimondi A, Pola S, Cattaneo MG, Francolini M, Vicentini LM, Pietrini G (2002) Invasive behaviour of glioblastoma cell lines is associated with altered organisation of the cadherin-catenin adhesion system. J Cell Sci 115:3331-3340.

Qi J, Chen N, Wang J, Siu CH (2005) Transendothelial migration of melanoma cells involves $\mathrm{N}$-cadherin-mediated adhesion and activation of the beta-catenin signaling pathway. Mol Biol Cell 16:4386-4397.

Reiss K, Maretzky T, Ludwig A, Tousseyn T, de Strooper B, Hartmann D, Saftig P (2005) ADAM10 cleavage of N-cadherin and regulation of cellcell adhesion and beta-catenin nuclear signalling. EMBO J 24:742-752.

Ridley AJ, Schwartz MA, Burridge K, Firtel RA, Ginsberg MH, Borisy G, Parsons JT, Horwitz AR (2003) Cell migration: integrating signals from front to back. Science 302:1704-1709.

Sanchez-Heras E, Howell FV, Williams G, Doherty P (2006) The fibroblast growth factor receptor acid box is essential for interactions with $\mathrm{N}$-cadherin and all of the major isoforms of neural cell adhesion molecule. J Biol Chem 281:35208-35216.

Sarkaria JN, Carlson BL, Schroeder MA, Grogan P, Brown PD, Giannini C, Ballman KV, Kitange GJ, Guha A, Pandita A, James CD (2006) Use of an orthotopic xenograft model for assessing the effect of epidermal growth factor receptor amplification on glioblastoma radiation response. Clin Cancer Res 12:2264-2271.

Shinojima N, Tada K, Shiraishi S, Kamiryo T, Kochi M, Nakamura H, Makino K, Saya H, Hirano H, Kuratsu J, Oka K, Ishimaru Y, Ushio Y (2003) Prognostic value of epidermal growth factor receptor in patients with glioblastoma multiforme. Cancer Res 63:6962-6970.

Shinoura N, Paradies NE, Warnick RE, Chen H, Larson JJ, Tew JJ, Simon M, Lynch RA, Kanai Y, Hirohashi S, Hemperly JJ, Menon AG, Brackenbury R (1995) Expression of $\mathrm{N}$-cadherin and alpha-catenin in astrocytomas and glioblastomas. Br J Cancer 72:627-633.
Shintani Y, Fukumoto Y, Chaika N, Grandgenett PM, Hollingsworth MA, Wheelock MJ, Johnson KR (2008) ADH-1 suppresses N-cadherindependent pancreatic cancer progression. Int J Cancer 122:71-77.

Stamenkovic I (2003) Extracellular matrix remodelling: the role of matrix metalloproteinases. J Pathol 200:448-464.

Sundberg C, Thodeti CK, Kveiborg M, Larsson C, Parker P, Albrechtsen R, Wewer UM (2004) Regulation of ADAM12 cell-surface expression by protein kinase C epsilon. J Biol Chem 279:51601-51611.

Suyama K, Shapiro I, Guttman M, Hazan RB (2002) A signaling pathway leading to metastasis is controlled by $\mathrm{N}$-cadherin and the FGF receptor. Cancer Cell 2:301-314.

Symowicz J, Adley BP, Gleason KJ, Johnson JJ, Ghosh S, Fishman DA, Hudson LG, Stack MS (2007) Engagement of collagen-binding integrins promotes matrix metalloproteinase-9-dependent E-cadherin ectodomain shedding in ovarian carcinoma cells. Cancer Res 67:2030-2039.

Todo T, Shitara N, Nakamura H, Takakura K, Ikeda K (1991) Immunohistochemical demonstration of protein kinase $\mathrm{C}$ isozymes in human brain tumors. Neurosurgery 29:399-403; discussion 403-394.

Tsuchiya B, Sato Y, Kameya T, Okayasu I, Mukai K (2006) Differential expression of $\mathrm{N}$-cadherin and E-cadherin in normal human tissues. Arch Histol Cytol 69:135-145.

Uemura K, Kihara T, Kuzuya A, Okawa K, Nishimoto T, Ninomiya H, Sugimoto H, Kinoshita A, Shimohama S (2006) Characterization of sequential N-cadherin cleavage by ADAM10 and PS1. Neurosci Lett 402:278-283.

Utsuki S, Sato Y, Oka H, Tsuchiya B, Suzuki S, Fujii K (2002) Relationship between the expression of E-, N-cadherins and beta-catenin and tumor grade in astrocytomas. J Neurooncol 57:187-192.

Utton MA, Eickholt B, Howell FV, Wallis J, Doherty P (2001) Soluble $\mathrm{N}$-cadherin stimulates fibroblast growth factor receptor dependent neurite outgrowth and $\mathrm{N}$-cadherin and the fibroblast growth factor receptor co-cluster in cells. J Neurochem 76:1421-1430.

Williams EJ, Williams G, Howell FV, Skaper SD, Walsh FS, Doherty P (2001) Identification of an $\mathrm{N}$-cadherin motif that can interact with the fibroblast growth factor receptor and is required for axonal growth. J Biol Chem 276:43879-43886. 